\title{
FAKTOR-FAKTOR YANG BERHUBUNGAN DENGAN KEJADIAN COMPUTER VISION SYNDROME PADA PEKERJA PENGGUNA KOMPUTER DI UNIVERSITAS IBN KHALDUN BOGOR TAHUN 2020
}

\author{
Rizkia Amelia Septiyanti ${ }^{1}$, Anissatul Fathimah ${ }^{2}$, Andi Asnifatima ${ }^{3}$ \\ ${ }^{1}$ Konsentrasi Kesehatan dan Keselamatan Kerja (K3), Program Studi Kesehatan Masyarakat Fakultas Ilmu \\ Kesehatan Universitas Ibn Khaldun Bogor. Jl. K.H Sholeh Iskandar Raya Km. 2, Kedung Badak, Bogor 16161, Jawa \\ Barat. Email : rizkiaamelia651@gamil.com \\ 2,3 Program Studi Kesehatan Masyarakat Fakultas Ilmu Kesehsatan Universitas Ibn Khaldun Bogor. Jawa Barat. \\ Email: ${ }^{1}$ anissatulfathimah@gmail.com, ${ }^{2}$ asni@uika-bogor.ac.id
}

\begin{abstract}
Abstrak
Prevalensi Computer Vision Syndrome mencapai 64-90\% pada pengguna Video Display Terminal dengan jumlah penderita di seluruh dunia diperkirakan sebesar 60 juta orang dan setiap tahun akan terus muncul 1 juta kasus baru. Tujuan dari penelitian ini adalah untuk mengetahui faktor yang berhubungan degan CVS.Penelitian ini menggunakan metode kuantitatif, dengan desain cross sectional. Populasi dalam penelitian ini sebanyak 150 pekerja Universitas Ibn Khaldun Bogor, sampel dalam penelitian ini sebanyak 68 responden. Analisis yang digunakan adalah univariat, chi square untuk analisis bivariat dan regresi logistik untuk analisis multivariat, teknik pengambilan sampel yang digunakan yaitu Simple Random Sampling. Alat penelitian yang digunakan adalah kuesioner, lux meter dan pita meteran. Variabel yang diteliti yaitu usia, jenis kelamin, lama bekerja dengan komputer, lama bekerja di depan komputer, lama istirahat, posisi bagian atas monitor dengan ketinggian horizontal mata, jarak penglihatan, tingkat pencahayaan. Dan cara analisis data dalam penelitian ini menggunakan perangkat statistik.Berdasarkan penelitian yang telah diteliti di Universitas Ibn Khaldun Bogor maka dapat disimpulkan bahwa pekerja yang mengalami keluhan CVS paling banyak adalah mata lelah dan tegang 69,1\%, variabel yang berhubungan dengan CVS adalah variabel lama bekerja dengan komputer, lama bekerja di depan komputer, lama istirahat, jarak penglihatan, tingkat pencahayaan. Variabel lama bekerja di depan komputer $>4$ jam sehari, 9 kali berisiko menyebabkan CVS pada pekerja pengguna komputer di Universitas Ibn Khaldun Bogor. Penelitian menunjukan bahwa faktor yang paling dominan berpengaruh terhadap CVS adalah lama bekerja di depan komputer.
\end{abstract}

Kata kunci : Computer Vision Syndrome, lama bekerja, pengguna komputer

\section{PENDAHULUAN}

Teknologi informasi adalah suatu teknologi yang digunakan untuk mengolah data, termasuk memproses, mendapatkan, menyusun, menyimpan, memanipulasi data dalam berbagai cara untuk menghasilkan informasi yang berkualitas, yaitu informasi yang relevan, akurat, dan tepat waktu, yang digunakan untuk keperluan pribadi, bisnis dan pemerintahan dan merupakan informasi yang strategis untuk pengambilan keputusan. Teknologi ini menggunakan seperangkat komputer untuk mengolah data, sistem jaringan untuk menghubungkan satu komputer dengan komputer yang lainnya sesuai dengan kebutuhan, 
dan teknologi telekomunikasi digunakan agar data dapat disebar dan diakses secara global (Wardiana, 2002).

Kemajuan teknologi informasi telah berkembang lebih dari 20 tahun, salah satunya dengan ditemukannya komputer. Penggunaan komputer menjadi bagian yang tidak dapat dipisahkan di tempat kerja karena memudahkan pekerjaan dan memberikan hasil yang lebih cepat. Namun, komputer dapat menimbulkan dampak bagi kesehatan. Komputer adalah suatu alat elektronik yang mampu melakukan tugas menerima input dan menyediakan output berupa hasil komputasi yang akan dikonversi menjadi data visual yang dapat dilihat dengan menggunakan monitor atau Video Display Terminal (Humaidi dan Alam, 2005). Komputer sudah menjadi bagian yang tidak dapat terpisahkan dan kehidupan bagi warga modern, penggunaan komputer selama berjam-jam tidak lagi terbatas pada kantor. Penggunaan komputer dapat menimbulkan sejumlah masalah penglihatan dan mata yang disebut Computer Vision Syndrome (CVS) (Barthakur, 2013).

Occupational safety and health administration (OHSA) mendefinisikan computer vision syndrome (CVS) sebagai keluhan mata dan penglihatan kompleks yang dialami ketika menggunakan komputer. Menurut Asosiasi Optometrik Amerika, CVS merupakan masalah mata majemuk yang berkaitan dengan pekerjaan jarak dekat yang dialami seseorang ketika menggunakan komputer. Tidak ada yang dapat menjelaskan penyebab pasti terjadinya CVS dikarenakan banyak faktor yang berperan dalam kejadian CVS diantaranya faktor individual, faktor lingkungan dan faktor komputer.

Computer Vision Syndrome dipengaruhi oleh faktor individual, faktor lingkungan, dan faktor komputer. Faktor-faktor individual yang berperan dalam terjadinya CVS antara lain: usia, jenis kelamin, penggunaan lensa kontak, penggunaan kacamata, lama bekerja dengan komputer, lama bekerja di depan komputer,dan lama istirahat setelah penggunaan komputer. Faktor-faktor yang berasal dari komputer di antaranya: jarak penglihatan, posisi bagian atas monitor terhadap ketinggian horizontal mata, polaritas monitor, dan jenis komputer.

Beberapa penelitian menyebutkan bahwa 90\% dari 70 juta pekerja di Amerika menggunakan komputer lebih dari 3 jam perhari. Rata-rata pekerja di Amerika menghabiskan waktu 7 jam per hari di kantor maupun di rumah menggunakan komputer. Jutaan kasus baru dapat terjadi setiap tahunnya. Keluhan CVS ditemukan di Malaysia sebesar 61,4\% pekerja mengalami nyeri punggung bagian bawah nyeri bahu dan leher sedangkan ketegangan pada mata terbanyak sebesar 70,6\%.

Peneliti luar negeri dari berbagai bidang (seperti Asosiasi Optometrik Amerika, kedokteran okupasi, manajemen bisnis dan teknologi, dan sebagainya) telah banyak melakukan penelitian mengenai faktor yang berhubungan dengan kerjadian CVS, tetapi sayangnya di Indonesia penelitian mengenai CVS masih belum banyak dilakukan padahal banyak pekerja perkantoran di Indonesia yang sehari-harinya menggunakan komputer.

Beberapa penelitian di Indonesia mengenai CVS, seperti dari penelitian Asnifatima, et al, menyatakan faktor risiko yang signifikan berhubungan adalah waktu istirahat < 2 jam, durasi penggunaan computer $>4$ jam, sudut penglihatan lebih tinggi, jarak penglihatan 4 jam yakni 27 kali lipat dibandingkan faktor risiko lainnya. Azkadina, menyatakan prevalensi penderita CVS sebesar 66,8\% pada responden Bank Jateng, RSI Sultan Agung dan RSUP dr. Kariadi. Darmaliputra, et al, menyatakan penderita CVS sebesar 74,0\% dengan keluhan CVS yang 
paling banyak dialami adalah mata lelah (91,1\%) pada responden Mahasiswa Jurusan Teknologi Informasi Universitas Udayana. Penelitian yang dilakukan Anggraini, menyatakan 88,5 \% responden mengalami keluhan CVS pada operator komputer PT. Bank Kalbar yang terbanyak dialami adalah astenopia, nyeri pada leher/ bahu dan punggung serta mata kering sebesar 23,2\%. Kusumawaty, et al, di PT Bank Indonesia - Makassar, menyatakan bahwa astenopia menjadi lebih berat dengan semakin banyaknya keluhan subjektif yang dialami seperti penurunan visus, dan terjadinya peningkatan risiko mata kering. Keluhan tersebut dapat menyebabkan menurunnya jam kerja dan mengurangi kenyamanan bekerja sehingga berdampak pada produktivitas kerja. Penurunan produktivitas kerja akibat CVS diperkirakan sebesar $40 \%$.

Computer Vision Syndrome sebenarnya bukan merupakan suatu sindrom yang mengancam nyawa. Manifestasi klinis dari sindrom ini mungkin dirasa tidak parah dan tidak mengganggu bagi sebagian orang. Hal tersebut memicu ketidakperdulian masyarakat dalam memeriksakan kesehatannya sehingga sindrom ini tidak mendapatkan penanganan yang tepat. Akibat yang selanjutnya terjadi jika sindrom ini tidak diatasi adalah hambatan dalam aktivitas sehari-hari, penurunan produktivitas kerja seseorang, peningkatan tingkat kesalahan dalam bekerja, dan penurunan kepuasan kerja. Dampak-dampak tersebut tentunya merugikan karena dapat menurunkan kualitas hidup seseorang.

Tidak ada yang dapat menjelaskan penyebab pasti terjadinya CVS dikarenakan banyak faktor yang berperan dalam kejadian CVS, diantaranya faktor individual, lingkungan dan komputer. Berdasarkan prinsip kesehatan kerja di Indonesia, Depkes RI mengelompokkan faktor tersebut kedalam prinsip K3 dasar meliputi faktor kapasitas kerja, beban kerja dan lingkungan kerja. Ketiga kelompok tersebut harus seimbang, masalah kesehatan kerja dapat timbul akibat ketidakseimbangan faktor tersebut.

Perkembangan teknologi saat ini memungkinkan manusia untuk lebih sering menggunakan teknologi dalam kehidupannya, sehingga dapat dikatakan penggunaan komputer akan meningkat seiring berjalannya waktu. Hal tersebut dapat meningkatkan insidensi CVS terutama jika faktor-faktor risiko yang ada tidak dideteksi dan dicegah lebih awal.

Beberapa hal tersebut menyebabkan CVS menjadi perhatian khusus bagi dunia kedokteran okupasi sehingga telah banyak dilakukan penelitian di luar negeri. Penelitian mengenai CVS di Indonesia belum banyak dilakukan oleh karena itulah peneliti ingin melakukan penelitian untuk mengetahui dampak penggunaan komputer dan faktor risikonya.

\section{METODE PENELITIAN}

Penelitian ini bersifat kuantitatif dengan jenis desain studi cross sectional. Pengambilan sampel dilakukan oleh peneliti sendiri, dengan cara memilih pekerja yang memenuhi kriteria inklusi sampai kriteria sampel minimal terpenuhi. Penyebaran kuesioner dilakukan pada 150 pekerja pengguna komputer Universitas Ibn Khaldun Bogor (total populasi), tetapi kuesioner yang diperoleh sebanyak 68 pekerja termasuk dalam kriteria eksklusi dikarenakan menolak mengisi kuesioner tanpa alasan, mengkonsumsi obat hipertensi, memakai lensa kontak. Teknik pengambilan sampel dilakukan dengan total sampling. 
Pengambilan sampel dilakukan secara bertahap, pada bulan November-Desember 2020 . Pengumpulan data dengan menggunakan kuesioner yang telah diuji validitas dan reliabilitasnya. Setelah pengisian kuesioner, dilanjutkan denga pengamatan ergonomi di stasiun kerja, pengukuran jarak penglihatan, dan pengukuran intensitas pencahayaan dengan menggunakan lux meter pada stasiun kerja. Pengolahan data menggunakan komputerisasi, dan analisis data dilakukan secara univariat, bivariat dengan uji chi-square dan multivariat dengan regresi logistik.

\section{HASIL PENELITIAN}

ANALISA UNIVARIAT

\section{Gambaran Computer Vision Syndrome}

Tabel 1. Gambaran CVS pada pekerja pengguna komputer di Universitas Ibn Khaldun Bogor Bulan Desember Tahun 2020.

\begin{tabular}{llcc}
\hline Variabel & Kategori & f & \% \\
\hline Computer & CVS (+) & 43 & 63,2 \\
Vision & CVS (-) & 25 & 36,8
\end{tabular}

Syndrome

Berdasarkan data pada tabel diatas didapatkan hasil bahwa sebagian besar pekerja mengalami CVS. Jenis keluhan yang dirasakan bervariasi. Dari 68 pekerja, yang mengalami CVS adalah sebanyak 43 responden (63,2\%), sedangkan pekerja yang tidak mengalami CVS adalah sebanyak 25 responden $(36,8 \%)$.

\section{Kejadian Computer Vision Syndrome (CVS)}

Tabel 2. Keluhan-keluhan CVS pada pekerja pengguna komputer di Universitas Ibn Khaldun Bogor Bulan Desember Tahun 2020.

\begin{tabular}{llcc}
\hline Keluhan & Kategori & f & $\mathbf{\%}$ \\
\hline Mata lelah dan tegang & Ya & 47 & 69,1 \\
& Tidak & 21 & 30,9 \\
\hline Penglihatan kabur & Ya & 25 & 36,8 \\
& Tidak & 43 & 63,2 \\
\hline Nyeri kepala & Ya & 25 & 36,8 \\
& Tidak & 43 & 63,2 \\
\hline Mata berair & Ya & 25 & 36,8 \\
& Tidak & 43 & 63,2 \\
\hline Mata kering teriritasi & Ya & 22 & 32,4 \\
& Tidak & 46 & 67,6 \\
\hline Mata terasa sakit & Ya & 19 & 27,9 \\
& Tidak & 49 & 72,1 \\
\hline Penglihatan ganda & Ya & 19 & 27,9 \\
& Tidak & 49 & 72,1 \\
\hline Sulit mengfokuskan penglihatan & Ya & 18 & 26,5 \\
& Tidak & 50 & 73,5 \\
\hline
\end{tabular}

Berdasarkan data pada tabel diatas diperoleh bahwa mayoritas responden mengeluhkan mata lelah dan tegang sebanyak 47 responden $(69,1 \%)$. Gejala yang paling sedikit dikeluhakan adalah sulit mengfokuskan penglihatan 18 responden $(26,5 \%)$. 


\section{Distribusi Variabel Independen}

Tabel 3. Distribusi responden menurut usia, jenis kelamin, lama bekerja dengan komputer, lama bekerja di depan komputer, lama istirahat, jarak penglihatan, posisi bagian atas monitor terhadap ketinggian horizontal mata, tingkat pencahayaan pada pekerja pengguna komputer di Universitas Ibn Khaldun Bogor Bulan Desember Tahun 2020.

\begin{tabular}{lcc}
\hline Variabel & Frekuensi & $\mathbf{\%}$ \\
\hline Usia & & \\
$<40$ tahun & 48 & 70,6 \\
$>40$ tahun & 20 & 29,4 \\
\hline Jenis kelamin & & \\
Laki-laki & 40 & 58,8 \\
Perempuan & 28 & 41,2 \\
\hline Lama bekerja dengan & & \\
komputer & & \\
$<5$ tahun & 47 & 69,1 \\
$>5$ tahun & 21 & 30,9 \\
\hline Lama bekerja di & & \\
depan komputer & & \\
$<4$ jam & 18 & 26,5 \\
$>4$ jam & 50 & 73,5 \\
\hline Lama istirahat & & \\
$<10$ menit & 53 & 77,9 \\
$>10$ menit & 15 & 22,1 \\
\hline Jarak penglihatan & & \\
$<50$ cm & 53 & 77,9 \\
$>50$ cm & 15 & 22,1 \\
\hline Posisi monitor & & \\
Lebih tinggi & 9 & 13,2 \\
Sejajar/Lebih rendah & 59 & 86,8 \\
\hline Tingkat pencahayaan & & 72,1 \\
Tidak standar & 49 & 27,9 \\
Standar & 19 & \\
\hline pada tabel diatas, mayar & & \\
\hline
\end{tabular}

Berdasarkan data pada tabel diatas, mayoritas usia responden berada pada usia kurang dari 40 tahun sebanyak 48 responden (70,6\%), mayoritas berjenis kelamin laki-laki sebanyak 40 responden $(58,8 \%)$, masa kerja responden kurang dari 5 tahun sebanyak 47 responden $(69,1 \%)$, mayoritas responden bekerja di depan komputer lebih dari 4 jam sebanyak 50 responden $(73,2 \%)$, lama istirahat responden kurang dari 10 menit sebanyak 53 responden (77,9\%), mayoritas responden mengatur jarak penglihatan kurang dari $50 \mathrm{~cm}$ sebanyak 53 responden $(77,9 \%)$, sebagian responden bekerja dengan posisi monitor sejajar/lebih rendah sebanyak 59 responden $(86,8 \%)$ dan mayoritas tingkat pencahayaan responden tidak standar sebanyak 49 responden $(72,1 \%)$. 


\section{ANALISA BIVARIAT}

Hubungan usia dengan kejadian CVS

Tabel 4. Hubngan usia dengan kejadian Computer Vision Syndrome pada pekerja pengguna komputer di Universitas Ibn Khaldun Bogor Tahun 2020

\begin{tabular}{|c|c|c|c|c|c|}
\hline \multirow{2}{*}{ Usia } & \multicolumn{2}{|c|}{ CVS } & \multirow[t]{2}{*}{ Total } & \multirow{2}{*}{$\begin{array}{c}\text { OR } \\
(95 \% \mathrm{CI})\end{array}$} & \multirow[t]{2}{*}{$P$-value } \\
\hline & $\mathrm{Ya}$ & Tidak & & & \\
\hline$<40$ tahun & 27 & 21 & 48 & 0,321 & \\
\hline$>40$ tahun & 16 & 4 & 20 & $\begin{array}{c}(0,093- \\
1,105\end{array}$ & 0,115 \\
\hline Total & 43 & 25 & 68 & & \\
\hline
\end{tabular}

Hasil uji chi-square diperoleh nilai p-value 0,115 maka dapat disimpulkan tidak ada hubungan yang signifikan antara usia dengan kejadian CVS pada pekerja pengguna komputer di Universitas Ibn Khaldun Bogor.

\section{Hubungan jenis kelamin dengan kejadian CVS}

Tabel 5. Hubungan jenis kelamin dengan kejadian Computer Vision Syndrome pada pekerja pengguna komputer di Universitas Ibn Khaldun Bogor Tahun 2020.

\begin{tabular}{|c|c|c|c|c|c|}
\hline \multirow{2}{*}{$\begin{array}{l}\text { Jenis } \\
\text { Kelamin }\end{array}$} & \multicolumn{2}{|c|}{ CVS } & \multirow[t]{2}{*}{ Total } & \multirow{2}{*}{$\begin{array}{c}\text { OR } \\
(95 \% \mathrm{CI})\end{array}$} & \multirow[t]{2}{*}{ P-value } \\
\hline & $\mathrm{Ya}$ & Tidak & & & \\
\hline Laki-laki & 25 & 15 & 40 & 0,936 & \\
\hline Perempuan & 18 & 10 & 28 & $\begin{array}{c}(0,339- \\
2,536)\end{array}$ & 1,000 \\
\hline Total & 45 & 56 & 68 & & \\
\hline
\end{tabular}

Hasil uji chi-square diperoleh nilai p-value 1,000 maka dapat disimpulkan tidak ada hubungan yang signifikan antara jenis kelamin dengan kejadian CVS pada pekerja pengguna komputer di Universitas Ibn Khaldun Bogor.

\section{Hubungan lama bekerja dengan komputer dengan kejadian CVS}

Tabel 6. Hubungan lama bekerja dengan komputer dengan kejadian Computer Vision Syndrome pada pekerja pengguna komputer di Universitas Ibn Khaldun Bogor.

\begin{tabular}{|c|c|c|c|c|c|}
\hline \multirow{2}{*}{$\begin{array}{l}\text { Lama bekerja } \\
\text { dengan komputer }\end{array}$} & \multicolumn{2}{|c|}{ CVS } & \multirow[t]{2}{*}{ Total } & \multirow{2}{*}{$\begin{array}{c}\text { OR } \\
(95 \% \mathrm{CI})\end{array}$} & \multirow{2}{*}{$\begin{array}{c}P- \\
\text { value }\end{array}$} \\
\hline & $\mathrm{Ya}$ & Tidak & & & \\
\hline$<5$ tahun & 34 & 13 & 21 & & \\
\hline$>5$ tahun & 9 & 12 & 47 & $\begin{array}{c}0,287 \\
(0,098- \\
0,840)\end{array}$ & 0,040 \\
\hline
\end{tabular}

\begin{tabular}{lrrr}
\hline Total & 43 & 25 & 68
\end{tabular}

Hasil uji chi-square diperoleh nilai p-value 0,040 maka dapat disimpulkan ada hubungan yang signifikan antara lama bekerja dengan komputer dengan kejadian CVS pada pekerja pengguna komputer di Universitas Ibn Khaldun Bogor. 
Hubungan lama bekerja di depan komputer dengan kejadian CVS

Tabel 7. Hubungan lama bekerja di depan komputer dengan kejadian Computer Vision Syndrome pada pekerja pengguna komputer di Universitas Ibn Khaldun Bogor Tahun 2020.

\begin{tabular}{lcccccc}
\hline $\begin{array}{l}\text { Lama bekerja di } \\
\text { depan komputer }\end{array}$ & \multicolumn{2}{c}{ CVS } & Total & $\begin{array}{c}\text { OR } \\
(\mathbf{9 5 \% C I})\end{array}$ & P-value \\
\cline { 2 - 5 } & Ya & Tidak & & & \\
\hline$<4$ jam & 16 & 2 & 18 & 6,815 & \\
\hline$>4$ jam & 27 & 23 & 50 & $\begin{array}{c}(1,415- \\
32,81\end{array}$ & 0,019 \\
& & & & &
\end{tabular}

\begin{tabular}{llll}
\hline Total & 43 & 25 & 68
\end{tabular}

Hasil uji chi-square diperoleh nilai $p$-value 0,019 maka dapat disimpulkan ada hubungan yang signifikan antara lama bekerja di depan komputer dengan kejadian CVS pada pekerja pengguna komputer di Universitas Ibn Khaldun Bogor.

\section{Hubungan lama istirahat dengan kejadian CVS}

Tabel 8. Hubungan lama istirahat dengan kejadian Computer Vision Syndrome pada pekerja pengguna komputer di Universitas Ibn Khaldun Bogor Tahun 2020.

\begin{tabular}{|c|c|c|c|c|c|}
\hline \multirow{2}{*}{$\begin{array}{l}\text { Lama } \\
\text { istirahat }\end{array}$} & \multicolumn{2}{|c|}{ CVS } & \multirow[t]{2}{*}{ Total } & \multirow{2}{*}{$\begin{array}{c}\text { OR } \\
(95 \% \mathrm{CI})\end{array}$} & \multirow{2}{*}{$\begin{array}{c}P- \\
\text { value }\end{array}$} \\
\hline & $\mathrm{Ya}$ & Tidak & & & \\
\hline$<10$ menit & 29 & 24 & 53 & 0,086 & \\
\hline$>10$ menit & 14 & 1 & 15 & $\begin{array}{c}(0,011- \\
0,705)\end{array}$ & 0,015 \\
\hline
\end{tabular}

Hasil uji chi-square diperoleh nilai $p$-value 0,015 maka dapat disimpulkan ada hubungan yang signifikan antara lama istirahat dengan kejadian CVS pada pekerja pengguna komputer di Universitas Ibn Khaldun Bogor.

Hubungan jarak penglihatan dengan kejadian CVS

Tabel 9. Hubungan jarak penglihatan dengan kejadian Computer Vision Syndrome pada pekerja pengguna komputer di Universitas Ibn Khaldun Bogor Tahun 2020.

\begin{tabular}{|c|c|c|c|c|c|}
\hline \multirow{2}{*}{$\begin{array}{l}\text { Jarak } \\
\text { penglihatan }\end{array}$} & \multicolumn{2}{|c|}{ CVS } & \multirow[t]{2}{*}{ Total } & \multirow{2}{*}{$\begin{array}{c}\text { OR } \\
(95 \% \mathrm{CI})\end{array}$} & \multirow{2}{*}{$\begin{array}{c}P- \\
\text { value }\end{array}$} \\
\hline & $\mathrm{Ya}$ & Tidak & & & \\
\hline$<50 \mathrm{~cm}$ & 29 & 24 & 53 & 0,086 & \\
\hline$>50 \mathrm{~cm}$ & 14 & 1 & 15 & $\begin{array}{c}(0,011- \\
0,705)\end{array}$ & 0,015 \\
\hline
\end{tabular}

Hasil uji chi-square diperoleh nilai $p$-value 0,015 maka dapat disimpulkan ada hubungan yang signifikan antara jarak penglihatan dengan kejadian CVS pada pekerja pengguna komputer di Universitas Ibn Khaldun Bogor. 


\section{Hubungan posisi bagian atas monitor terhadap ketinggian horizontal mata}

Tabel 10. Hubungan posisi bagian atas monitor terhadap ketinggian horizontal mata dengan kejadian Computer Vision Syndrome pada pekerja pengguna komputer di Universitas Ibn Khaldun Bogor Tahun 2020.

\begin{tabular}{|c|c|c|c|c|c|}
\hline \multirow{2}{*}{ Posisi monitor } & \multicolumn{2}{|c|}{ CVS } & \multirow[t]{2}{*}{ Total } & \multirow{2}{*}{$\begin{array}{c}\text { OR } \\
(95 \% \mathrm{CI})\end{array}$} & \multirow{2}{*}{$\begin{array}{c}P \text { - } \\
\text { value }\end{array}$} \\
\hline & $\mathrm{Ya}$ & Tidak & & & \\
\hline Lebih tinggi & 5 & 4 & 9 & 0,691 & \\
\hline $\begin{array}{l}\text { Sejajar/lebih } \\
\text { rendah }\end{array}$ & 38 & 21 & 59 & $\begin{array}{l}(0,167- \\
2,854)\end{array}$ & 0,887 \\
\hline Total & 43 & 25 & 68 & & \\
\hline
\end{tabular}

Hasil uji chi-square diperoleh nilai p-value 0,887 maka dapat disimpulkan tidak ada hubungan yang signifikan antara posisi bagian atas monitor terhadap ketinggian horizontal mata dengan kejadian CVS pada pekerja pengguna komputer di Universitas Ibn Khaldun Bogor.

Hubungan tingkat pencahayaan dengan kejadian CVS

Tabel 11. Hubungan tingkat pencahayaan dengan kejadian Computer Vision Syndrome pada pekerja pengguna komputer di Universitas Ibn Khaldun Bogor Tahun 2020.

\begin{tabular}{|c|c|c|c|c|c|}
\hline \multirow{2}{*}{$\begin{array}{l}\text { Tingkat } \\
\text { pencahayaan }\end{array}$} & \multicolumn{2}{|c|}{ CVS } & \multirow[t]{2}{*}{ Total } & \multirow{2}{*}{$\begin{array}{c}\text { OR } \\
(95 \% \mathrm{CI})\end{array}$} & \multirow[t]{2}{*}{ P-value } \\
\hline & $\mathrm{Ya}$ & Tidak & & & \\
\hline Tidak standar & 26 & 23 & 49 & 0,133 & \\
\hline Standar & 17 & 2 & 19 & $\begin{array}{l}(0,028- \\
0,639)\end{array}$ & 0,012 \\
\hline
\end{tabular}

Hasil uji chi-square diperoleh nilai $p$-value 0,012 maka dapat disimpulkan ada hubungan yang signifikan antara tingkat pencahayaan dengan kejadian CVS pada pekerja pengguna komputer di Universitas Ibn Khaldun Bogor.

\section{ANALISIS MULTIVARIAT}

\section{Seleksi Bivariat}

Tabel 12. Hasil seleksi bivariat variabel independen dengan variabel dependen

\begin{tabular}{lcc}
\hline \multicolumn{1}{c}{ Variabel } & P-value & P-value $<\mathbf{0 , 2 5}$ \\
\hline Usia & 0,056 & $\sqrt{ }$ \\
Jenis Kelamin & 0,880 & $\mathrm{x}$ \\
Lama Bekerja dengan Komputer & 0,021 & $\sqrt{ }$ \\
Lama Bekerja di Depan Komputer & 0,005 & $\sqrt{ }$ \\
Lama Istirahat & 0,003 & $\sqrt{ }$ \\
Jarak Penglihatan & 0,09 & $\sqrt{ }$ \\
Posisi Bagian Atas Monitor terhadap & 0,612 & $\mathrm{x}$ \\
Ketinggian Horizontal Mata & & $\sqrt{ }$ \\
Tingkat Pencahayaan & 0,003 &
\end{tabular}

Hasil seleksi bivariat semua variabel menghasilkan $P$-value $<0,25$, didapat variabel jenis kelamin dan posisi bagian atas monitor terhadap ketinggian horizontal mata yang $P$ valuenya $>0,25$. 


\section{Pemodelan Multivariat}

Tabel 13. Pemodelan regresi logistik pemodelan bersama

\begin{tabular}{lcccc}
\hline \multicolumn{1}{c}{ Variabel } & B & P-value & OR & 95\% CI \\
\hline Usia & $-0,533$ & 0,517 & 0,587 & $0,117-2,948$ \\
Lama Bekerja dengan & $-0,697$ & 0,308 & 0,498 & $0,130-1,903$ \\
Komputer & & & & \\
\hline $\begin{array}{l}\text { Lama Bekerja di } \\
\text { Depan Komputer }\end{array}$ & 1,859 & 0,034 & 6,418 & $1,151-35,795$ \\
\hline Lama Istirahat & $-1,793$ & 0,132 & 0,166 & $0,016-1,718$ \\
\hline Jarak Penglihatan & $-1,657$ & 0,075 & 0,191 & $0,031-1,181$ \\
\hline Tingkat Pencahayaan & $-1,904$ & 0,034 & 0,149 & $0,26-0,862$ \\
\hline
\end{tabular}

Dilakukan eliminasi variabel yang P-valuenya $>0,05$. Dari pemodelan pertama terlihat ada tiga variabel yang $P$-valuenya $>0,05$ yaitu usia, lama bekerja dengan komputer dan lama istirahat. Eliminasi pertama, variabel yang $P$-valuenya $>0,05$ dan terbesar dikeluarkan dari model yaitu usia.

Tabel 14. Pemodelan regresi logistik pemodelan kedua

\begin{tabular}{|c|c|c|c|c|}
\hline Variabel & $\mathbf{B}$ & P-value & OR & $95 \%$ CI \\
\hline $\begin{array}{l}\text { Lama Bekerja dengan } \\
\text { Komputer }\end{array}$ & $-0,820$ & 0,214 & 0,440 & $0,121-1,606$ \\
\hline $\begin{array}{l}\text { Lama Bekerja di Depan } \\
\text { Komputer }\end{array}$ & 1,870 & 0,032 & 6,486 & $1,177-35,753$ \\
\hline Lama Istirahat & $-1,790$ & 0,129 & 0,167 & $0,017-1,680$ \\
\hline Jarak Penglihatan & $-1,586$ & 0,084 & 0,205 & $0,034-1,236$ \\
\hline Tingkat Pencahayaan & $-1,884$ & 0,033 & 0,152 & $0,027-0,860$ \\
\hline
\end{tabular}

Hasil perhitungan perubahan nilai OR lama bekerja dengan komputer $(8,8 \%)$, lama bekerja di depan komputer (6,3\%), lama istirahat (9,5\%), jarak penglihatan $(9,4 \%)$, tingkat pencahayaan $(9,6 \%)$. Sehingga usia tetap dikeluarkan dari model, eliminasi berikutnya adalah lama bekerja dengan komputer.

Tabel 15. Pemodelan regresi logistik pemodelan ketiga

\begin{tabular}{lcccc}
\hline \multicolumn{1}{c}{ Variabel } & B & P-value & OR & 95\% CI \\
\hline Lama Bekerja di Depan & 2,010 & 0,021 & 7,464 & $1,355-41,121$ \\
Komputer & & & & \\
Lama Istirahat & $-1,872$ & 0,103 & 0,154 & $0,016-1,459$ \\
Jarak Penglihatan & $-1,577$ & 0,082 & 0,207 & $0,035-1,222$ \\
Tingkat Pencahayaan & $-1,942$ & 0,025 & 0,143 & $0,026-0,796$
\end{tabular}

Hasil perhitungan perubahan nilai OR lama bekerja di depan komputer $(8,8 \%)$, lama istirahat $(9,6 \%)$, jarak penglihatan $(9,4 \%)$, tingkat pencahayaan $(9,6 \%)$. Sehingga lama bekerja dengan komputer tetap dikeluarkan dari model, eliminasi berikutnya adalah lama istirahat. 
Tabel 16. Pemodelan regresi logistik pemodelan keempat

\begin{tabular}{lcccc}
\hline \multicolumn{1}{c}{ Variabel } & B & P-value & OR & 95\% CI \\
\hline Lama Bekerja di & 2,272 & 0,008 & 9.703 & $1,821-51,686$ \\
Depan Komputer & & & & \\
Jarak Penglihatan & $-1,948$ & 0,024 & 0,142 & $0,026-0,777$ \\
Tingkat & $-1,988$ & 0,020 & 0,137 & $0,026-0,734$ \\
Pencahayaan & & & & \\
\hline
\end{tabular}

Hasil perhitungan perubahan nilai OR lama bekerja di depan komputer $(8,8 \%)$, jarak penglihatan $(9,6 \%)$, tingkat pencahayaan $(9,6 \%)$. Dari analisis multivariat ternyata variabel yang berhubungan bermakna dengan kejadian CVS pada pekerja pengguna komputer di Universitas Ibn Khaldun Bogor tahun 2020 adalah variabel lama bekerja di depan komputer, jarak penglihatan dan tingkat pencahayaan. Hasil analisis Odds Ratio (OR) dari variabel lama bekerja di depan komputer adalah 9,703 (95\% CI= 1,821-48,153), artinya pekerja yang bekerja di depan komputer lebih dari 4 jam secara terus-menerus berisiko menderita CVS 9 kali lebih tinggi dibandingkan pekerja yang bekerja di depat komputer kurang dari 4 jam. Variabael yang paling dominan berhubungan dengan kejadian CVS adalah lama bekerja di depan komputer.

Dari hasil analisis, diketahui bahwa koefisien determinan (R square) menunjukan nilai 0,391, artinya bahwa model regresi yang diperoleh dapat menjelaskan 39,1\% variasi variabel dependen Computer Vision Syndrome. Dengan demikian, lama bekerja di depan komputer, jarak penglihatan, dan tingkat pencahayaan hanya dapat menjelaskan variasi variabel Computer Vision Syndrome sebesar 39,1\%, sedangakan 60,9\% dijelaskan variabel lainnya yang tidak diteliti.

\section{PEMBAHASAN}

\section{Hubungan Usia dengan Kejadian CVS}

Hasil uji yang dilakukan dalam penelitian ini didapatkan $P$-value $0,115(P$-value $>0,05)$ menunjukan bahwa tidak ada hubungan yang bermakna antara variabel usia dengan kejadian CVS. Hasil OR 0,321 dengan rentang confidence interval (CI) 0,093-1,105 menunjukan bahwa usia tidak berisiko terhadap kejadian CVS. Sebagian besar responden ini berusia kurang dari 40 tahun sebanyak 48 responden (70,6\%). Responden yang berusia lebih dari 40 tahun sebanyak 20 orang $(29,4 \%)$. Analisis multivariat yang telah dilakukan diatas, menunjukan bahwa tidak ada hubungan usia dengan kejadian CVS dalam penelitian ini.

Hasil penelitian diatas sejalan dengan hasil penelitian (Amira Azkadina, 2012) yang berjudul "hubungan antara faktor risiko individual dan komputer terhadap kejadian Computer Vision Syndrome". Ditunjukan usia dengan nilai $P$-value $=1,000$ ( $P$-value 1,000>0,05), maka tidak ada hubungan antara usia dengan kejadian CVS. Sebagian besar responden penelitian ini berusia kurang dari 40 tahun (73,3\%).

Hasil ini berbeda dengan studi oleh Das et al menyatakan bahwa pekerja pengguna komputer yang berusia lebih dari 40 tahun mengeluhkan rasa ketidaknyamanan menggunakan komputer yang berkaitan dengan kesehatan, dengan tingkat tertinggi dibandingkan dengan kelompok usia lain. Hal tersebut bisa dijelaskan sebagai suatu akibat proses penuaan yang menimbulkan penurunan fungsi tubuh, dalam hal ini adalah fungsi penglihatan. Pertambahan usia akan menyebabkan kepadatan sel pada kornea menurun dan 
perubahan morfologi dari sel endotel kornea, yang berakibat kornea menjadi lebih rentan terhadap stress atau jejas.

\section{Hubungan Jenis kelamin dengan kejadian CVS}

Hasil uji yang dilakukan dalam penelitian ini didapatkan $P$-value $1,000(P$-value $>0,05)$ menunjukan bahwa tidak ada hubungan yang bermakna antara variabel jenis kelamin dengan kejadian CVS. Hasil OR 0,936 dengan rentang confidence interval (CI) 0,339-2,256 menunjukan bahwa jenis kelamin tidak berisiko terhadap kejadian CVS. Responden penelitian ini sebanyak 28 orang (41,2\%) berjenis kelamin perempuan, sedangkan responden yang berjenis kelamin laki-laki sebanyak 40 orang (58,8\%). Analisis multivariat yang telah dilakukan diatas, menunjukan bahwa tidak ada hubungan jenis kelamin dengan kejadian CVS dalam penelitian ini.

Hasil penelitian diatas sejalan dengan hasil penelitian (Farras Putri Arianti, 2017) yang berjudul "faktor-faktor yang berpengaruh dengan keluhan kelelahan mata pada pekerja pengguna komputer di call center PT.AM". Ditunjukan jenis kelamin dengan nilai $P$-value = 0,184 ( $P$-value $0,184>0,05)$, maka tidak ada hubungan antara jenis kelamin dengan kejadian CVS.

Computer Vision Syndrome lebih banyak di kalangan laki-laki daripada perempuan. Lakilaki berada pada risiko yang lebih tinggi mengalami CVS dengan gejala kemerahan, sensasi terbakar, penglihatan kabur, dan mata kering. Namun sakit kepala, leher, dan nyeri bahu relatif lebih banyak pada wanita. Laki-laki memiliki risiko lebih tinggi terkena mata kering (Logaraj, Madhupriya dan Hegde, 2014).

Banyak penelitian yang menyebutkan bahwa kejadian CVS pada perempuan lebih banyak dari pada laki-laki walaupun tidak berbeda secara bermakna. Secara fisiologis, lapisan tear film pada perempuan cenderung lebih cepat menipis seiring dengan meningkatnya usia. Penipisian tear film menyebabkan mata terasa kering, yang juga merupakan salah satu gejala CVS. Perbedaan fisiologis lainnya adalah penurunan sekresi air mata, perbedaan ukuran atau massa tubuh, dan fungsi hormon. Selain itu, perempuan memiliki tingkat stress yang lebih tinggi yang tidak berkaitan dengan pekerjaan, yaitu mengurus anak dan pekerjaan rumah. Perempuan juga lebih sering mendatangi pelayanan kesehatan jika merasakan suatu ketidaknyamanan pada tubuhnya.

\section{Hubungan Lama bekerja dengan komputer dengan kejadian CVS}

Responden penelitian ini lebih banyak responden yang bekerja dengan komputer kurang dari 5 tahun sebanyak 47 orang $(69,1 \%)$. Sedangkan responden yang bekerja lebih dari 5 tahun sebanyak 21 orang (30.9\%).

Hasil uji yang dilakukan dalam penelitian ini didapatkan $P$-value $0,040(P$-value $<0,05)$ menunjukan bahwa ada hubungan yang bermakna antara variabel lama bekerja dengan komputer dengan kejadian CVS. Hasil OR 0,287 dengan rentang confidence interval (CI) 0,0980,840 menunjukan bahwa lama bekerja dengan komputer merupakan faktor protektif terhadap kejadian CVS, artinya lama bekerja dengan komputer kurang dari 5 tahun dapat menurunkan resiko terhadap kejadian CVS. Peneliti mendapatkan bahwa sebagian responden yang bekerja dengan komputer kurang dari 5 tahun dengan angka kejadian CVS lebih tinggi 
pada kelompok tersebut sebanyak 34 (72,3\%), mungkin dikarenakan instansi tersebut melakukan regenerasi pekerja, pekerja yang telah bekerja dengan komputer lebih dari 5 tahun digantikan oleh pekerja yang baru, sehingga pekerjaan lebih banyak dibebankan pada pekerja yang baru atau pekerja yang bekerja dengan komputer kurang dari 5 tahun. Analisis multivariat yang telah dilakukan diatas, menunjukan bahwa tidak ada hubungan lama bekerja dengan komputer dengan kejadian CVS dalam penelitian ini.

Hasil penelitian diatas sejalan dengan hasil penelitian (Nopriadi et al, 2019) yang berjudul "faktor yang berhubungan dengan kejadian Computer Vision Syndrome pada karyawan bank". Ditunjukan lama bekerja dengan komputer dengan nilai $P$-value $=0,002(P$ value $0,002<0,05$ ), maka ada hubungan antara lama bekerja dengan komputer dengan kejadian CVS.

Reddy et al, mengutip dari Bergqvist dan Knave; Sanchez-Roman et al, yang mengemukakan bahwa masa kerja dengan komputer berhubungan langsung dengan gejala pada mata, panjangnya durasi cenderung menimbulkan keluhan-keluhan menetap bahkan setelah selesai bekerja. Masa kerja menggunakan komputer berhubungan dengan lamanya durasi kerja, dapat berefek langsung pada mata sehingga keluhan yang muncul ini lebih sering diabaikan dan akhirnya menetap bahkan setelah selesai bekerja.

\section{Hubungan Lama bekerja di depan komputer dengan kejadian CVS}

Hasil uji yang dilakukan dalam penelitian ini didapatkan $P$-value 0,019 ( $P$-value $<0,05)$ menunjukan bahwa ada hubungan yang bermakna antara variabel lama bekerja di depan komputer dengan kejadian CVS. Hasil OR 6,815 dengan rentang confidence interval (CI) 1,415-32,81 menunjukan bahwa lama bekerja di depan komputer komputer berisiko terhadap kejadian CVS. Responden pada penelitian ini lebih banyak responden yang bekerja di depan komputer selama lebih dari 4 jam secara terus-menerus, yaitu sebanyak 50 orang (73,5\%). Sedangkan responden yang bekerja di depan komputer kurang dari 4 jam sebanyak 18 orang $(26,5 \%)$. Analisis multivariat yang telah dilakukan diatas, menunjukan bahwa ada hubungan lama bekerja di depan komputer dengan kejadian CVS dalam penelitian ini. Pekerja yang bekerja di depan komputer lebih dari 4 jam secara terus-menerus akan mempunyai odds (berisiko) mengalami kejadian CVS 9 kali lebih tinggi dibandingkan pekerja yang bekerja di depan komputer kurang dari 4 jam (95\% CI=1,727-48,153).

Hasil penelitian ini mendukung penelitian yang dilakukan (Nopriadi et al, 2019) yang berjudul "faktor yang berhubungan dengan kejadian Computer Vision Syndrome pada karyawan bank". Ditunjukan lama bekerja di depan komputer dengan nilai $P$-value = 0,002 $(P$ value $0,000<0,05)$, maka ada hubungan antara lama bekerja dengan komputer dengan kejadian CVS.

Hasil penelitian ini sesuai dengan penelitian sebelum-sebelumnya. Lamanya bekerja di depan komputer merupakan faktor risiko kejadian mata tegang, jika bekerja kurang dari lima jam sehari memiliki odds ratio 3,1 sedangkan jika bekerja lebih dari lima jam sehari nilai odds ratio menjadi lebih tinggi yaitu 5,4. Studi oleh Edema et al. mendapatkan bahwa 53,15\% responden menggunakan komputer secara terus-menerus selama empat jam menyebabkan mereka lebih berisiko mengalami stress akibat penggunaan komputer. Studi sebelumnya oleh Sanchez-Roman et al. melaporkan bahwa bekerja secara terus-menerus selama empat jam di 
depan komputer tanpa diselingi istirahat berasosiasi secara signifikan dengan kejadian astenopia.

Hasil penelitian ini juga sesuai dengan penelitian yang dilakukan oleh Ellahi et al, dalam penelitiannya menemukan hubungan pengguna komputer yang lama lebih dari 4 jam per hari dapat menimbulkan kejadian CVS, stress, kelainan otot tulang dan rangka serta carpal tunnel syndrome.

Kebanyakan karyawan hanya beristirahat setelah 4 jam bekerja yaitu ketika jam istirahat. NIOSH dan AOA merekomendasikan rule of 20-20-20 untuk mencegah keluhan CVS artinya karyawan yang menggunakan momlouter dianjurkan untuk istirahat selaam 20 detik setelah 20 menit menggunakan komputer (istirahat tanpa meninggalkan stasiun kerja, tetap melakukan pekerjaan lain menggunakan komputer), dan memandang objek yang berada pada jarak 20 kaki ( \pm 6 meter) ini bertujuan untuk mengurangi ketegangan pada otot yang menggerakan bola mata (kelelahan otot terjadi setelah 15-20 menit bekerja tanpa istirahat) dan dengan melihat jarak \pm 6 meter diharapkan mata akan relaksasi. Rule of 20-20-20 ini dapat dijalankan dengan cara sosialisasi melalui penyuluhan, saling mengingatkan antar karyawan dan memasang poster di dinding atau meja kerja.

\section{Hubungan Lama istirahat dengan kejadian CVS}

Hasil uji yang dilakukan dalam penelitian ini didapatkan $P$-value $0,015(P$-value $<0,05)$ menunjukan bahwa ada hubungan yang bermakna antara variabel lama istirahat dengan kejadian CVS. Hasil OR 0,086 dengan rentang confidence interval (CI) 0,011-0,705 menunjukan bahwa lama istirahat merupakan faktor protektif terhadap kejadian CVS. Responden penelitian yang menyempatkan istirahat selama kurang dari 10 menit ada sebanyak 53 orang (77,9\%). Sedangkan responden yang menyempatkan istirahat selama lebih dari 10 menit sebanyak 15 orang $(22,1 \%)$. Analisis multivariat yang telah dilakukan diatas, menunjukan bahwa tidak ada hubungan lama istirahat dengan kejadian CVS dalam penelitian ini.

Hasil penelitian diatas sejalan dengan hasil penelitian (Amira Azkadina, 2012) yang berjudul "hubungan antara faktor risiko individual dan komputer terhadap kejadian Computer Vision Syndrome". Ditunjukan lama istirahat dengan nilai $P$-value $=0,000$ (P-value $0,000<0,05$ ), maka ada hubungan antara lama istirahat dengan kejadian CVS.

Hal ini sesuai dengan teori dan penelitian sebelumnya oleh Ye et al. yang menyatakan bahwa istirahat selama 10-15 menit setelah penggunaan komputer merupakan faktor protektif terhadap munculnya keluhan CVS sedangkan tidak menyempatkan istirahat merupakan faktor risiko dengan odds ratio sebesar 5,1.

Banyak responden yang menyampaikan bahwa mereka menyempatkan istirahat hanya sekitar 5-10 menit lalu kembali bekerja di depan komputer dengan alasan tuntutan pekerjaan yang banyak dan harus segera diselesaikan. NIOSH dan AOA merekomendasikan rule of 2020-20 untuk mencegah keluhan CVS artinya pekerja yang menggunakan komputer dianjurkan untuk istirahat selama 20 detik setelah 20 menit menggunakan komputer (istirahat tanpa meninggalkan stasiun kerja, tetap melakukan pekerja lain selain menggunakan komputer), dan memandang objek yang berada pada jarak 20 kaki $( \pm 6$ meter) ini bertujuan untuk mengurangi ketegangan pada otot yang menggerakkan bola mata (kelelahan otot terjadi 
setelah 15-20 menit bekerja tanpa istirahat) dan dengan melihat jarak \pm 6 meter diharapkan mata akan relaksasi.

\section{Hubungan Jarak penglihatan dengan kejadian CVS}

Hasil uji yang dilakukan dalam penelitian ini didapatkan $P$-value $0,0115(P$-value $<0,05)$ menunjukan bahwa ada hubungan yang bermakna antara variabel jarak penglihatan dengan kejadian CVS. Hasil OR 0,162 dengan rentang confidence interval (CI) 0,034-0,784 menunjukan bahwa jarak penglihatan merupakan faktor protektif terhadap kejadian CVS. Responden yang mengatur jarak penglihatan sejauh lebih dari $50 \mathrm{~cm}$ sebanyak 15 orang $(22,1 \%)$, selisih cukup besar dengan responden yang mengatur jarak penglihatan sejauh kurang dari $50 \mathrm{~cm}$. Responden yang mengatur jarak penglihatan kurang dari $50 \mathrm{~cm}$ sebanyak 53 orang $(77,9 \%)$. Analisis multivariat yang telah dilakukan diatas, menunjukan bahwa ada hubungan jarak penglihatan dengan kejadian CVS dalam penelitian ini.

Hasil penelitian diatas sejalan dengan hasil penelitian (Amira Azkadina, 2012) yang berjudul "hubungan antara faktor risiko individual dan komputer terhadap kejadian Computer Vision Syndrome". Ditunjukan jarak penglihatan dengan nilai P-value $=0,000$ ( $P$-value $0,000<0,05)$, maka ada hubungan antara lama istirahat dengan kejadian CVS.

Hal ini sesuai dengan teori dan penelitian sebelumnya Chiemeke at al, melaporkan bahwa keluhan adanya gangguan penglihatan lebih banyak pada pekerja dengan jarak penglihatan kurang dari 10 inci $(25,4 \mathrm{~cm})$. Studi oleh Taptagaporn et al. melaporkan bahwa jarak penglihatan yang direkomendasikan adalah 50-70 cm dan studi lain menyatakan bahwa semakin jauh monitor diletakkan (90-100 cm) maka dapat meminimalisasi timbulnya keluhan penglihatan.

Hasil penelitian ini juga sesuai dengan penelitian yang dilakukan oleh Shantakumari et al, pada pelajar di Ajman, Arab Saudi, diperoleh bahwa pelajar yang melihat layar komputer dengan jarak < $50 \mathrm{~cm}$ bekerja dalam waktu yang lama dengan komputer, keluhan menjadi berkurang jika jarak penglihatannya ditingkatkan $50 \mathrm{~cm}$. OSHA menjelaskan bahwa jarak yang dianjurkan untuk melihat monitor komputer berkisar $18-24$ inchi $(45,72-60,96 \mathrm{~cm})$, rata-rata berjarak $50,80 \mathrm{~cm}$.

\section{Hubungan Posisi bagian atas monitor terhadap ketinggian horizontal mata dengan kejadian CVS}

Hasil uji yang dilakukan dalam penelitian ini didapatkan $P$-value 0,887 ( $P$-value $>0,05)$ menunjukan bahwa tidak ada hubungan yang bermakna antara variabel posisi bagian atas monitor terhadap ketinggian horizontal mata dengan kejadian CVS. Hasil OR 0,691 dengan rentang confidence interval (CI) 0,167-2,854 menunjukan bahwa posisi bagian atas monitor terhadap ketinggian horizontal mata tidak berisiko terhadap kejadian CVS. Sebagian besar responden 59 orang $(86,8 \%)$ bekerja dengan posisi bagian atas monitor lebih rendah atau sejajar terhadap ketinggian horizontal mata. Sedangkan responden yang bekerja dengan posisi bagian atas monitor lebih tinggi sebanyak 9 orang $(13,2 \%)$. Analisis multivariat yang telah dilakukan diatas, menunjukan bahwa tidak ada hubungan posisi bagian atas monitor terhadap ketinggian horizontal mata dengan kejadian CVS dalam penelitian ini. 
Hasil penelitian diatas sejalan dengan hasil penelitian (Amira Azkadina, 2012) yang berjudul "hubungan antara faktor risiko individual dan komputer terhadap kejadian Computer Vision Syndrome". Ditunjukan posisi bagian atas monitor terhadap ketinggian horizontal mata dengan nilai $P$-value $=1,000(P$-value $1,000>0,05)$, maka tidak ada hubungan antara usia dengan kejadian CVS.

Hasil penelitian ini tidak sesuai dengan teori yang menyatakan bahwa posisi bagian atas monitor dapat menjadi faktor yag menimbulkan keluhan-keluhan akibat pengguanaan komputer. Hal tersebut dikarenakan mayoritas responden telah memposisikan bagian atas monitor sejajar atau lebih rendah daripada ketinggian horizontal mata. Hal itu menandakan bahwa responden telah mengetahui posisi yang baik antara monitor dengan mata yang dapat meminimalisasi timbulnya keluhan kesehatan.

\section{Hubungan Tingkat pencahayaan dengan kejadian CVS}

Hasil uji yang dilakukan dalam penelitian ini didapatkan $P$-value $0,012(P$-value $<0,05)$ menunjukan bahwa ada hubungan yang bermakna antara variabel tingkat pencahayaan dengan kejadian CVS. Hasil OR 0,133 dengan rentang confidence interval (CI) 0,028-0,639 menunjukan bahwa tingkat pencahayaan merupakan faktor protektif terhadap kejadian CVS. Hasil penelitian ini terdapat 49 meja kerja (72,1\%) dengan tingkat pencahayaan yang tidak memenuhi standar, sedangkan hanya terdapat 19 meja kerja $(27,9 \%)$ dengan tingkat pencahayaan yang telah memenuhi standar. Analisis multivariat yang telah dilakukan diatas, menunjukan bahwa ada hubungan tingkat pencahayaan dengan kejadian CVS dalam penelitian ini.

Hasil penelitian ini mendukung penelitian yang dilakukan (Nopriadi et al, 2019) yang berjudul "faktor yang berhubungan dengan kejadian Computer Vision Syndrome pada karyawan bank". Ditunjukan tingkat pencahayaan dengan nilai $P$-value $=0,001$ ( $P$-value $0,001<0,05)$, maka ada hubungan antara lama bekerja dengan komputer dengan kejadian CVS.

Hasil penelitian ini sesuai dengan penelitian yang dilakukan oleh Shantakumari, bahwa penggunaan komputer dalam ruangan yang sangat terang atau pada ruangan yang gelap dapat menyebabkan gangguan penglihatan. Ruangan yang terlalu terang menyebabkan sakit kepala dan ruangan yang terlalu gelap dapat menyebabkan mata kering. Pencahayaan komputer dan kontrasnya harus seimbang dengan pencahyaan ruangan.

Kondisi pencahayaan yang buruk dari daerah sekitar komputer dapat mempengaruhi mata pengguna. Pencahayaan terang dari sekitarnya (lampu neon, jendela yang besar, lampu meja) dapat mengganggu gambar karakter layar yang dapat menciptakan silau dan refleksi. Hal ini menyebabkan gangguan dan kelelahan visual. Telah terbukti bahwa pencahayaan sekitarnya secara signifikan mengurangi amplitude akomodasi. Silau menyebabkan keterlambatan dalam waktu membaca ketika itu tidak mungkin untuk mengubah system pencahayaan sekitarnya. Penangkal anti silau digunakan untuk mengurangi itu (Abelson dan Ousler, 1999; Wimalasundera, 2006). 


\section{KESIMPULAN DAN SARAN}

1. Sebanyak $63,2 \%$ pekerja pengguna komputer di Universitas Ibn Khaldun Bogor tahun 2020 mengalami Computer Vision Syndrome.

2. Jenis keluhan keluhan Computer Vision Syndrome paling bayak dikeluhkan oleh pekerja pengguna komputer di Universitas Ibn Khaldun Bogor tahun 2020 adalah mata lelah dan tegang, yaitu sebesar $69,1 \%$.

3. Gambaran faktor individual pada pekerja pengguna komputer di Universitas Ibn Khaldun Bogor tahun 2020, yaitu:

a. Seluruh pekerja pengguna komputer di Universitas Ibn Khaldun Bogor Tahun 2020 masuk ke dalam kelompok usia tidak berisiko, yaitu $<40$ tahun.

b. Sebagian besar pekerja pengguna komputer di Universitas Ibn Khaldun Bogor tahun 2020 , yaitu $58,8 \%$ berjenis kelamin laki-laki.

c. Sebagian besar pekerja pengguna komputer di Universitas Ibn Khaldun Bogor, yaitu 69,1\% bekerja dengan komputer lebih dari 5 tahun.

d. Sebanyak 73,5\% pekerja pengguna komputer di Universitas Ibn Kaldun Bogor tahun 2020 bekerja di depan komputer selama lebih dari 4 jam secara terus-menerus.

e. Sebanyak 77,9\% pekerja pengguna komputer di Universitas Ibn Khaldun Bogor tahun 2020 menyempatkan istirahat selama kurang dari 10 menit.

4. Gambaran faktor komputer pada pekerja pengguna komputer di Universitas Ibn Khaldun Bogor tahun 2020, yaitu:

a. Sebagian besar pekerja pengguna komputer di Universitas Ibn Khaldun Bogor tahun 2020, yaitu $86,8 \%$ bekerja dengan posisi bagian atas monitor lebih rendah atau sejajar terhadap ketinggian horizontal mata.

b. Sebanyak $77,9 \%$ pekerja pengguna komputer di Universitas Ibn Khaldun Bogor tahun 2020 mengatur jarak penglihatannya kurang dari $50 \mathrm{~cm}$.

5. Gambaran faktor lingkungan kerja pada pekerja pengguna komputer di Universitas Ibn Khaldun Bogor tahun 2020, yaitu 72,1\% meja kerja tidak memiliki tingkat pencahayaan yang standar $(<315$ atau $>385$ lux $)$.

6. Hubungan faktor individual pada pekerja pengguna komputer di Universitas Ibn Khaldun Bogor tahun 2020, yaitu:

a. Tidak ada hubungan antara usia dengan kejadian Computer Vision Syndrome (CVS) pada pekerja pengguna komputer di Universitas Ibn Khaldun Bogor tahun 2020.

b. Tidak ada hubungan antara jenis kelamin dengan kejadian Computer Vision Syndrome (CVS) pada pekerja pengguna komputer di Universitas Ibn Khaldun Bogor tahun 2020.

c. Ada hubungan antara lama bekerja dengan komputer dengan kejadian Computer Vision Syndrome (CVS) pada pekerja pengguna komputer di Universitas Ibn Khaldun Bogor tahun 2020.

d. Ada hubungan antara lama bekerja di depan komputer dengan kejadian Computer Vision Syndrome (CVS) pada pekerja pengguna komputer di Universitas Ibn Khaldun Bogor tahun 2020.

e. Ada hubungan antara lama istirahat dengan kejadian Computer Vision Syndrome (CVS) pada pekerja pengguna komputer di Universitas Ibn Khaldun Bogor tahun 2020. 
7. Tidak ada hubungan antara posisi bagian atas monitor dengan ketinggian horizontal mata dengan kejadian Computer Vision Syndrome (CVS) pada pekerja pengguna komputer di Universitas Ibn Khaldun Bogor tahun 2020.

8. Ada hubungan antara jarak penglihatan dengan kejadian Computer Vision Syndrome (CVS) pada pekerja pengguna komputer di Universitas Ibn Khaldun Bogor tahun 2020.

9. Ada hubungan antara tingkat pencahayaan dengan kejadian Computer Vision Syndrome (CVS) pada pekerja pengguna komputer di Universitas Ibn Khaldun Bogor tahun 2020.

10. Faktor yang paling dominan berpengaruh dengan kejadian Computer Vision Syndrome (CVS) pada pekerja pengguna komputer di Universitas Ibn Khaldun Bogor tahun 2020 adalah lama bekerja di depan komputer.

Disarankan kepada pihak Universitas Ibn Khaldun untuk lebih memperhatikan aspek keselamatan da kesehatan kerja di perkantoran yaitu mengatur stasiun kerja yang ergonomis, mensosialisasikan risiko dan upaya pencegahan gangguan kesehatan bagi pekerja pengguna komputer salah satunya CVS dengan memasang poster di dinding dan mengatur program time warning yang diinstal pada komputer. Kepada pekerja agar mealkukan metode 20-20-20 setiap jam, artinya setiap 20 menit, melihat sesuatu dari kejauhan berjarak 20 feet atu 6 meter selam 20 etik, melakukan peregangan dan pengaturan pencahayaan sesuai standar.

\section{DAFTAR PUSTAKA}

Affandi, Edi, S. 2005. Sindrom Penglihatan Komputer (Computer Vision Syndrome). Majalah Kedokteran Indonesia. 2005;55(3). (Diakses 24 februari 2020).

Aldino. 2017. Hubungan Kelelahan Mata dengan Penggunaan Laptop pada Mahasiswa di Universitas Ibn Khaldun Bogor. Universitas Ibn Khaldun. Bogor. (Diakses 20 februari 2020).

American Optometric Association (AOA). 1997. The effects of computer use on eye health and vision. http: www.aoa. org/documents, EffectsComputerUse.pdf. (Diakses 25 februari 2020).

America Optometric Association (AOA). 2015. The Effects of Computer Use on Eye Health and Vision. 2015. http://www.aoa.org. (Diakses 25 februari 2020).

American Optometric Association (AOA). 2017. Computer Vision Syndrome. http://www.aoa.org/patients-and-public/caring-for-your-vision/protecting-yourvision/computer-vision-syndrome?sso=y. (Diakses 25 februari 2020).

Anggraini. 2013. Faktor yang Berhubungan dengan Terjadinya Keluhan Computer Vision Syndrome (CVS) pada Operator Komputer PT Bank Kalbar. (Diakses 25 februari 2020).

Arianti, Putri, Farras. 2016. Faktor-Faktor yang Berhubungan dengan Keluhan Kelelahan Mata pada Pekerja Pengguna Komputer di Call Center PT. AM. Uiversitas Islam Negeri Syarif Hidayatullah. Jakarta. (Diakses pada tanggal 29 februari 2020).

Azkadina, A. 2012. Hubungan Antara Faktor Risiko Individual Dan Komputer Terhadap Kejadian Computer Vision Syndrome. Universitas Diponegoro. Semarang. (Diakses 25 februari 2020).

Badan Standarisasi Nasional. 2001. Standar Nasional Indonesia (SNI). SNI 03-6575-2001. Tata Cara Perancangan Sistem Pencahayaan Buatan pada Bangunan Gedung. Jakarta: Dewan Standarisasi Indonesia. 
Badan Standarisasi Nasional. 2004. Standar Nasional Indonesia (SNI). SNI 16- 7062-2004. Pengukuran Intensitas Penerangan di Tempat Kerja. Jakarta: Dewan Standarisasi Indonesia.

Blehm C, Vishnu S, Khattak A, Mitra S, Yee RW. 2005. Computer vision syndrome: a review. J Surv Ophthal. 50(3) : 253-262.

Baqir, M, 2017. Hubungan Lama Penggunaan Komputer Dengan Kejadian Computer Vision Syndrome Pada Pegawai Pengguna Komputer Di Universitas Muhammadiyah Palembang. Universitas Muhammadiyah. Palembang. (Diakses 26 februari 2020).

Cabrera S, Lim Bon Siong R. 2010. A survey of eye-related complaints among call-center agents in Metro Manila. Philipp J Ophthalmol. 35(2):65-9.

Damiri, Cinthya, Debb, 2018. Computer Vision Syndrome dan Faktor-faktor yang Mempengaruhinya pada Mahasiswa Jurusan Ilmu Komputer Fakultas Matematika dan Iolmu Pengetahuan Alam Universitas Lampung. Universitas Lampung. Lampung. (Diakses 18 Agustus 2021).

Departemen Kesehatan RI. 2008. Pencahayaan Salah Perburuk Penglihatan. Jakarta: Departemen Kesehatan.

Fadhillah, Luthfiana, Selisca, 2013. Faktor-Faktor Yang Berhubungan Dengan Keluhan Kelelahan Mata Pada Pengguna Komputer Di Accounting Group PT Bank X Jakarta. Universitas Islam Syarif Hidayatullah. Jakarta. (Diakses 29 februari 2020).

Hastono, Priyo, S. 2017. Analisis Data pada Bidang Kesehatan. Depok: RajaGrafindo Persada. (Hastono, 2017)

Kementerian Kesehatan RI. 2019. Teknik Pencegahan Computer Vision Syndrome (CVS) dengan 20-20-20 Rule. Jakarta: Kementerian Kesehatan.

Keputusan Menteri Kesehatan No. 261/MEN-KES/SK/II/1998. Persyaratan Kesehatan Lingkungan Kerja. Depkes RI; 1998. (Diakses 25 februari 2020).

Keputusan Menteri Kesehatan Republik Indonesia Nomor 1405/MENKES/SK/XI/2002 tentang Persyaratan Kesehatan Lingkungan Kerja Perkantoran dan Industri.

Kusumawaty, S., Syawal, Siti R., Sirajuddin, Junaedi. 2012. Computer Vision Syndrome Pada Pegawai Pengguna Komputer di PT. Bank Negara Indonesia (Persero) TBK Makassar. (Diakses 25 februari 2020).

Loh KY, Reddy SC. 2008. Understanding and preventing computer vision syndrome. Malaysian Family Physician. 3(3).

NIOSH. 1999. NIOSH Publications on Video Display Terminals - Third Edition. Ohio: U.S. Department of Health and Human Services.

Notoatmodjo, Soekidjo. 2003. Ilmu Kesehatan Masyarakat, Prinsip-Prinsip Dasar. Cetakan ke-2. Jakarta: Rineka Cipta.

Nugroho, Hengki Ditya Eko. 2009. Pengaruh Intensitas Penerangan Terhadap Kelelahan Mata pada Tenaga Kerja di Laboratorium PT. Polypet Karyapersada Cilegon. Program Diploma IV Kesehatan Kerja. Fakultas Kedokteran. Universitas Sebelas Maret. Surakarta.

Occupational Safety and Health Administration (OSHA). 1997. Working Safety with Video Display Terminal. (Diakses 19 februari 2020). 
Octavia S. 2016. Faktor-faktor yang berhubungan dengan kejadian computer vision syndrome pada operator komputer PT. Bank Lampung, Provinsi Lampung. Fakultas Kedokteran Universitas Lampung. Bandar Lampung.

Peraturan Menteri Kesehatan Republik Indonesia Nomor 48 Tahun 2016 tentang Standar Keselamatan dan Kesehatan Kerja Perkantoran.

Peraturan Menteri Kesehatan Republik Indonesia Nomor 70 Tahun 2016 tentang Standar dan Syarat Kesehatan Lingkungan Kerja.

Permana, Melati Aisyah, dkk. 2015. Faktor Yang Berhubungan dengan Keluhan Computer Vision Syndrome (CVS) pada Pekerja Rental Komputer di Wilayah UNNES. Unnes Journal of Public Health, 4(3).

Rahman, Topan Aditya. 2015. Analisis Statistik Penelitian Kesehatan (Prosedur Pemilihan Uji Hipotesis Penelitian Kesehatan). Bogor : IN Media Anggota IKAPI.

Ranasinghe, et al. 2016. Computer vision syndrome among computer office workers in a developing country: an evaluation of prevalence and risk factors. BioMed Central. 9:150 DOI 10.1186/s13104-016-1962-1

Rosenfield, M. 2011, Computer vision syndrome: a review of ocular causes and potential treatments. Ophthalmic and Physiological Optics. 31 (5): 502- 515. (Diakses 26 februari 2020).

Rosenfield, M., dkk. 2010. Computer Vision Syndrome: Accomodative \& Vergence Facility. Journal of Behavioral Optometry. 21 (5). (Diakses 26 februari 2020).

Tarwaka, dkk. 2004. Ergonomi untuk Keselamatan, Kesehatan Kerja, dan Produktivitas. Surakarta: UNIBA PRESS.

Shantakumari, N., dkk. 2014. Computer Use and Vision-Related Problems Among University Students In Ajman, United Arab Emirate. Annals of Medical and Health Sciences Research, $4(2), 258-263$.

Sheedy, J. E., dan Shaw-McMinn, P. G. 2003. Diagnosing and treating computerrelated vision problems. Elsevier Health Sciences. (Diakses pada tanggal 25 februari 2020).

Utami, Wiga. Virgian. 2014. Analisis Faktor yang Berhubungan Dengan Kejadian Computer Vision Syndrome (CVS) pada Karyawan Harian Sumatera Ekspre Group Palembang. Universitas Sriwijaya.

Wahyudi, Desi. 2006. Studi tentang Penerangan dan Keluhan Kelelahan Mata pada Pengguna Komputer Di Bagian Akuntansi Umum Biro Akuntansi PT. Petro Kimia Gresik, Jawa Timur. Fakultas Kesehatan Masyarakat. Universitas Airlangga. 